\title{
Pengembangan Kompetensi di Masa Pandemi COVID 19
}

\author{
Nadella \\ Universitas Presiden \\ Dedi Rianto Rahadi \\ Universitas Presiden \\ lay.nadella17@gmail.com \\ dedi1968@president.ac.id
}

\begin{abstract}
Abstrak
Indonesia mulai tergguncang pandemi covid19 pada awal Maret 2020 yang menyebabkan para karyawan serta calon karyawan mulai kebingungan dalam bertahan di kondisi ini. Tak sedikit juga perusahaan meminimalisirkan lowongan kerja serta melakukan PHK. Demi bertahan hidup di masa pandemi ini, masyarakat dianjurkan untuk dapat mengetahui serta mengembangkan kompetensi yang dimiliki agar dapat tetap bersaing di dunia kerja kembali. Dari hasil pengumpulan data maupun wawancara, kompetensi seperti Information Technology (IT) memiliki banyak peluang pada kondisi ini dikarenakan pekerjaan dialihkan menjadi work from home ( WFH ) serta persiapan kondisi yang serba digital. Tak hanya bagian IT, bagian customer service sangat diminati banyak perusahaan karena terjadinya peningkatan di pembelian online, sehingga para pengusaha membutuhkan karyawan yang berkompeten dalam bidang tersebut. Pengembangan dapat diasah dengan training yang diberikan oleh perusahaan secara online. Para HRD juga harus dapat menciptakan feedback yang positif dimana tetap melakukan interaksi terhadap karyawan agar hubungan timbal balik tetap ada..
\end{abstract}

Kata Kunci: Covid 19, kompetensi, perusahaan, karyawan, IT, digital, WFH, training, online, customer service

\section{Pendahuluan}

Pandemi Covid 19 mulai masuk ke Indonesia saat terdengar 2 kasus positif pada tanggal awal Maret 2020 (Tim Detik.com, 2020, https://news.detik.com/berita/d-4991485/kapansebenarnya-corona-pertama-kali-masuk-ri, 6 Januari 2021). Semakin bertambah hari, kasus corona di Indonesia semakin meningkat. Untuk memutuskan rantai penyebaran, pemerintah mengeluarkan Peraturan Pemerintah Nomor 21 Tahun 2020 tentang Pedoman PSBB atau Pembatasan Sosial Berskala Besar (Satgas Covid19,2020, https://covid19.go.id/p/regulasi/ppno-21-tahun-2020-tentang-psbb-dalam-rangka-penanganan-covid-19, 6 Januari 2021) .

Selama PSBB berlangsung di Indonesia, seluruh sektor industri terpaksa dihentikan sementara untuk mengikuti aturan pemerintah. Adanya aturan pemerintah mengenai PSBB, perekonomian di Indonesia menjadi terganggu. Sektor- sektor industri yang bukan merupakan bagian pangan, kesehatan, keuangan, komunikasi, serta listrik melakukan kegiatan ekonomi melalui daring. Akan tetapi sebagain perusahaan juga terdapat yang memutuskan untuk mengurangi karyawan yang bekerja di tempat kerja. Demi menyelamatkan perusahaan, para karyawan diwajibkan untuk tetap bekerja di rumah menggunakan perangkat yang mendukung. Sebagian perusahaan juga menerapkan PHK atau Pemberhentian Hubungan Kerja untuk menyelamatkan biaya operasional. Hal tersebut membuat angka pengangguran di Indonesia semakin meningkat. Dampak seperti ini membuat perusahaan ataupun pemilk usaha berpikir 


\section{Nadella, Dedi Rianto Rahadi}

ulang bagaimana mempertahankan perusahaan dan tetap memikirkan hak para pekerja serta strategi yang harus dilakukan dalam kondisi apapun.

Selama pandemi ini berlangsung, tidak banyak perusahaan yang membuka lowongan pekerjaan. Hanya beberapa divisi yang membuka lowongan pekerjaan. Keadaan seperti ini membuat masyarakat harus bertahan bekerja secara daring dan memperisapkan diri agar menjadi kandidat baru dalam perusahaan di masa pandemi ini bukan sesuatu hal yang mudah. Para pencari kerja termasuk siswa yang berstatus fresh graduate juga mengalami hambatan dalam pencarian kerja di masa pandemi seperti ini. Divisi yang diinginkan para lulusan baru tersebut tidak semua terdaftar di website atau tempat pencarian pekerja baru sehingga niat mereka untuk mencari kerja harus tertunda.

Para karyawan dan calon karyawan harus menyadari perubahan yang ada serta mempersiapkan diri dalam menghadapi keadaan yang serba digital. Untuk bersaing di dunia bisnis, setiap orang harus memiliki kompetensi. Menurut Namira dalam Wibowo (2015) menyatakan "kompetensi ialah suatu kemampuan untuk melaksanakan atau melakukan suatu pekerjaan yg dilandasi atas keterampilan dan pengetahuan serta didukung sang perilaku kerja yang dituntut sang pekerjaan tadi”. Kompetensi dapat berupa skill dan knowledge yang berkaitan dengan bidang tertentu. Sebuah kompetensi sangat berpengaruh terhadap hasil kerja perusahaan sehingga pertimbangan pemilihan karyawan menjadi salah satu yang dilakukan oleh setiap perushaan (Yostan dalam Noe, 2019). Pandemi ini menyadari masyarakat agar dapat mengembangkan kompetensi tertentu untuk terpilih menjadi seorang kandidat baru kompetensi yang diharapkan juga sesuai dengan perubahan yang terjadi di masa pandemi korona ini.

Banyak masyarakat yang belum menyadari perubahan yang terjadi terutama cara operasi di dunia bisnis. Dari sisi perusahaan pun saat ini sedang berusaha tetap mengoptimalkan pengembangan kompetensi dengan tetap menjaga protokol kesehatan untuk mematuhi peraturan pemerintah. Tidak sedikit usaha besar ataupun kecil belum mengetahui cara pengoptimalan pengembangan kompetensi karyawan serta calon karyawan. Oleh karena itu, kejadian pandemi ini menjadi alasan jurnal ini terbuat untuk mengetahui kompetensi yang diharapkan saat ini oleh perusahaan agar masyarakat dapat mempersiapkan diri serta menyadari apa yang harus dilatih serta dikembangkan. Jurnal ini juga membantu usaha kecil atapun besar dalam melakukan pengembangan kompetensi. Tujuan penelitian ini yaitu untuk mengetahui kompetensi apa yang harus dikembangkan serta cara dalam mengembangkannya di masa pandemi ini.

\section{Landasan Teori}

\section{Pengembangan}

PSDM pada organisasi bersifat integral menjadi individu dan sistem dan organisasi menjadi wadah SDM secara berkala dan berkesinambungan buat menigkatkan kompetensi pekerja melalui program pelatihan, pendidikan, serta pengembangan. Konsep Pengembangan sumber Daya manusia (PSDM) di organisasi, hakikatnya ialah suatu perjuangan demi peningkatan daya saing terhadap ancaman lingkungan eksternal dan upaya menaikkan daya inovatif demi menciptkan peluang dimana kegiatan tersebut dapat meningkatkan kompetensi karyawan dari program-program pelatihan yang diberikan perusahaan. (Yostan dalam Noe, 2019). Secara umum PSDM bertujuan buat: 


\section{Nadella, Dedi Rianto Rahadi}

1. membentuk individu asal aspek-aspek ketrampilan, pengetahuan serta perilaku;

2. pengembangan karir;

3. mengatur dan membina manusia sebagai sub sistem organisasi melalui program-acara perencana serta evaluasi mirip perencanaan energi kerja, evaluasi kinerja, analisis pekerjaan, serta penjabaran pekerjaan

4. menerima sdm sesuai penjabaran kebutuhan organisasi serta indera organisasi yang bertujuan buat perbaikan serta peningkatan;

5. penyesuaian sistem serta kebijakan organisasi menjadi penangkal risiko serta faktor eksternal.

\section{Kompetensi}

Pengertian kompetensi adalah suatu "kemampuan yang dimiliki oleh seorang dalam melaksanakan sebuah pekerjaan atau tugas di bidang eksklusif, sinkron memakai jabatan yg disandangnya".

Nur dalam Dessler (2018) menyatakan pentingnya kompetensi karyawan adalah sebagai berikut:

1. Untuk mengetahui cara berpikir sebab-akibat yang kritis

2. Strategis antara asal daya insan dan kinerja perusahaan merupakan peta strategis yang menyebutkan proses implementasi strategis perusahaan.

3. Memahami prinsip pengukuran yang baik

4. Pondasi dasar kompetansi manajemen manapun sangat bergantung pada pengukuran yang baik. Khususnya, pengukuran harus menjelaskan dengan benar konstruksi tersebut.

5. Memastikan hubungan sebab-akibat (causal)

6. Tugas yang paling krusial merupakan buat merealisasikan bahwa perkiraan tersebut ialah mungkin serta mengkalkulasikannya menjadi suatu kesempatan yang timbul.

7. Mengkomunikasikan hasil kerja strategis sumber daya manusia pada atasan

8. Untuk mengatur kinerja strategis asal daya insan, wajib mampu mengkomunikasikan pemahaman mengenai dampak strategis asal daya insan terhadap atasan.

Dimensi dan Indikator Kompetensi Beberapa aspek yang terkandung dalam konsep kompetensi menurut Nur dalam Gordon dalam Sutrisno (2018) sebagai berikut:

1. Pengetahuan (knowledge) pencerahan dalam bidang kognitif. misalnya seorang karyawan mengetahui cara melakukan identifikasi belajar serta bagaimana melakukan pembelajaran yang baik sesuai dengan kebutuhan yang ada menggunakan efektif serta efisien di perusahaan.

2. Pemahaman (understanding) Kedalam kognittif dan afektif yang dimiliki individu. misalnya seseorang karyawan pada melaksanakan pembelajaran harus mempunyai pemahaman yang baik tetang karakteristik dan kondisi secara efektif dan efisien.

3. Kemampuan/Keterampilan (skill) Sesuatu yang dimiliki oleh individu yang melaksanakan tugas atau pekerjaan yang dibebankan kepadanya. misalnya, kemampuan karyawan pada memilih metode kerja yang disebut lebih efektif dan efisien.

4. Nilai (value) Suatu standar perilaku yang sudah ditakini serta secara psikologis telah menyatu dalam diri seseorang. misalnya, baku sikap para karyawan dalam melaksanakan tugas (kejujuran, keterbukaan, demokratis serta lainlain).

5. Sikap (attitude) Perasaan (suka -tidak senang, senang-tidak senang) atau reaksi terhadap suatu rangsangan yang tiba asal luar. misalnya, reaksi terhadap krisis ekonomi, perasaan terhadap kenaikan gaji serta sebagainya. 


\section{Nadella, Dedi Rianto Rahadi}

6. Minat (interest) Kecenderungan seseorang untuk melakukan suatu perbuatan. contohnya, melakukan sesuatu aktivitas tugas.

\section{Pandemi Covid 19}

COVID-19 merupakan penyakit menular yang paling baru ditemukan akibat paparan dari virus korona. Awal mula virus ini diketahui berasal dari negara Wuhan,Cina yang terjadi pada bulan Desember 2019. Virus Covid-19 telah menyerang hampir seluruh negara di dunia ini sehingga dapat disebut sebagai pandemi.

WHO sedang di dalam proses melakukan penelitian mengenai cara penyebaran dari virus COVID-19 dengan tetap membagikan temuan baru. Seseorang dapat dikatakan tertular orang yang dinyatakan positif COVID-19 melalui tetesan kecil yang berasal dari hidung ataupun mulut dari orang ke orang pada saat pasien tersebut melakukan batuk, berbicara, dan juga bersin. Tetesan tersebut dikatakan relatif berat dikarenakan pergerakan terjadi sangat dekat dan mudah tenggelam ke tanah. Pentingnya menjaga jarak paling tidak satu meter dari penderita agar tidak terjadi terhirupnya atau terkenanya tetesan dari penderita COVID-19. Setiap masyarakat dianjurkan untuk mencuci tangan dengan sabun ataupun menggunakan antiseptik yang terdapat kandungan alkohol secara berkala hingga bersih dikarenakan apabila seseorang menyentuh beberapa permukaan yang berkompeten menjadi titik terjatuhnya tetesan kecil seperti gagang pintu, meja, ataupun sentuhan tangan maka virus tersebut akan menyebar.

\section{Metode Penelitian}

Dalam penelitian ini menggunakan metode kualitatif. Menurut McCusker, K., \& Gunaydin, S. (2015), metode kualitatif digunakan untuk menjawab pertanyaan tentang "apa (what)", "bagaimana (how)", atau "mengapa (why)" atas suatu fenomena. Penggunaaan metode kualitatif untuk memastikan kualitas dari proses penelitian, sebab peneliti tadi akan menginterpretasi data yang telah dikumpulkannya.

Teknik yang digunakan dalam metode ini yaitu pengumpulan data. Data akan didapatkan berasa dari hasil wawancara dan beberapa sumber yang berada di internet mengenai kompetensi yang sedang diminati oleh banyak perusahaan serta cara pengembangan kompetensi yang dapat dilakukan di masa pandemi covid 19 ini. Penentuan narasumber didasarkan oleh survey penulis di lingkungan sekitar dengan mempertimbangkan usaha yang dijalankan sesuai dengan judul penelitian ini yaitu berpacu terhadap strategi bertahan di kondisi pandemi ini serta usaha yang terdampak akibat pandemi. Penelitian akan dilanjutkan dengan mengaitkan teori dengan data yang telah dikumpulkan.

Wawancara dilakukan terhadap dua pemilik usaha online, yaitu :

1. Narasumber 1 : Herna Angelica, pemilik usaha Serendiptydesign

2. Narasumber 2 : Dinar Dinasty Lutfia, pemlik usaha Herskinnn

Dimana pertanyaan yang diajukan peneliti kepada narasumber yaitu :

1. Apa nama usaha yang sedang anda jalankan ?

2. Apa yang anda pelajari untuk mempertahankan usaha anda di tengah pandemi ?

3. Bidang pekerjaan apa uamh anda akan berikan dalam usaha anda di tengah pandemi ini? 


\section{Nadella, Dedi Rianto Rahadi}

4. Kualifikasi apa yang anda butuhkan apabila atau sedang mencari karyawan ?

5. Kepribadian seperti apa yang anda butuhkan?

6. Training seperti apa yang akan anda lakukan untuk mengembangkan kompetensi karyawan anda?

\section{Pembahasan}

Dalam penelitian ini menggunakan teknik wawancara terhadap kedua pemilik usaha online mengenai kompetensi ataupun kualifikasi apa yang dibutuhkan saat pandemi COVID-19 ini melalui bidang pekerjaan yang sedang atau akan narasumber berikan terhadap calon karyawan. Hasil wawancara dalam penelitian ini yaitu :

Tabel 1. Hasil Wawancara dengan Narasumber 1

\begin{tabular}{|c|l|}
\hline Peneliti & Apa nama usaha yang sedang anda jalankan ? \\
\hline Narasumber 1 & Jasa line art bernama Serendiptydesign \\
\hline Peneliti & Apa yang anda pelajari untuk mempertahankan usaha anda di tengah pandemi ? \\
\hline Narasumber 1 & $\begin{array}{l}\text { Sering melakukan promosi memberikan promo, serta membuka dropshipper via } \\
\text { shopee }\end{array}$ \\
\hline Peneliti & $\begin{array}{l}\text { Bidang pekerjaan apa yang anda akan berikan dalam usaha anda di tengah } \\
\text { pandemi ini ? }\end{array}$ \\
\hline Narasumber 1 & Bidang design \\
\hline Peneliti & Kualifikasi apa yang anda butuhkan apabila atau sedang mencari karyawan ? \\
\hline Narasumber 1 & Dapat menggunakan Photoshop atau sejenisnya, dapat menggambar \\
\hline Peneliti & Kepribadian seperti apa karyawan yang anda butuhkan ? \\
\hline Narasumber 1 & Dapat bekerja keras, tanggung jawab, bekerja di bawah tekanan, kreatif \\
\hline Peneliti & $\begin{array}{l}\text { Training seperti apa yang akan anda lakukan untuk mengembangkan kompetensi } \\
\text { karyawan anda ? }\end{array}$ \\
\hline Narasumber 1 & Workshop dam seminar \\
\hline
\end{tabular}

Tabel 2. Hasil Wawancara dengan Narasumber 2

\begin{tabular}{|c|l|}
\hline Peneliti & Apa nama usaha yang sedang anda jalankan ? \\
\hline Narasumber 2 & Bidang skincare bernama Herskinnn \\
\hline Peneliti & Apa yang anda pelajari untuk mempertahankan usaha anda di tengah pandemi ? \\
\hline Narasumber 2 & Membuat konten di sosial media untuk menarik perhatian konsumen \\
\hline Peneliti & $\begin{array}{l}\text { Bidang pekerjaan apa yang anda akan berikan dalam usaha anda di tengah } \\
\text { pandemi ini ? }\end{array}$ \\
\hline Narasumber 2 & Bidang customer service \\
\hline Peneliti & Kualifikasi apa yang anda butuhkan apabila atau sedang mencari karyawan ? \\
\hline Narasumber 2 & $\begin{array}{l}\text { Dapat menggunakan Microsoft untuk pengolahan penjualan, dapat bekerja sesuai } \\
\text { target }\end{array}$ \\
\hline Peneliti & Kepribadian seperti apa karyawan yang anda butuhkan ? \\
\hline Narasumber 2 & Ramah terhadap customer \\
\hline Peneliti & $\begin{array}{l}\text { Training seperti apa yang akan anda lakukan untuk mengembangkan kompetensi } \\
\text { karyawan anda ? }\end{array}$ \\
\hline Narasumber 2 & Memberikan latihan secara online dengan mengutamakan interaksi \\
\hline
\end{tabular}




\section{Nadella, Dedi Rianto Rahadi}

Menurut hasil dari wawancara yang telah dilakukan dengan dua pemilik usaha online di bidang berbeda, menunjukkan dalam masa pandemi ini pemilk usaha lebih fokus terhadap perkembangan dari usaha masing-masing melalui media sosial yang ada. Kedua pemilik usaha tersebut membutuhkan calon pekerja yang dapat melayani konsumen serta skill tertentu yang mendukung bidang usaha tersebut, seperti pada narasumber 1 membutuhkan karyawan yang dapat melakukan kegiatan design, sedangkan pada narasumber 2 membutuhkan karyawan yang dapat mengoprasikan Microsoft untuk mengelola hasil penjualan. Pengembangan kompetensi karyawan dari kedua pemilik usaha tersebut lebih menekankan melalui online dimana narasumber 2 juga mementingkan interaksi antara pemilk usaha serta calon karyawan.

Menurut CNN Indonesia, Pada masa pandemi ini membuat sebagaian perusahaan harus melakukan pengurangan bahkan tidak membuka rekrutmen. Sektor ekonomi menjadi lumpuh akibat pandemi ini sehingga perusahaan terpaksa melakukan PHK atau yang dapat kita sebut Pemutusan Hubungan Kerja. Walaupun di kondisi pandemi covid 19 ini, tidak sedikit perusahaan yang tetap membuka beberapa divisi pekerjaan. Pekerjaan itu ialah :

\section{a. Tenaga Kesehatan}

Profesi ini sangat dibutuhkan untuk menolong pasien positif korona, dimana pemerintah pun sampai membutuhkan relawan, seperti salah satunya relawan perawat di Rumah Sakit Darurat Wisma Atlet Kemayoran.

\section{b. Guru Privat}

Akibat rasa tertekan yang dialami orang tua dalam mengajari anak-anaknya, profesi guru privat sangat dicari dalam masa pandemi ini. Dengan hadirnya guru privat, setidaknya meringankan sedikit beban orang tua. Sebab menjadi guru dengan penguasaan materi cukup sulit dilakukan.

\section{c. Psikolog}

Di masa pandemi ini dibutuhkan sosok psikologi untuk memberikan solusi akan rasa kekhawatiran yang terjadi. Hal tersebut dibutuhkan karena pemberintaan di media tentang pertambahan kasus korona.

\section{d. Kurir Barang dan Makanan}

Terjadi peningkatan penggunaan belanja online semenjak seluruh masyarakat dihimbau di rumah saja. Peningkatan tersebut membuat kurir kewalahan untuk memenuhi permintaan konsumen. Kejadian tersebut membuat perusahaan ekspedisi membutuhkan karyawan baru sesuai dengan standar yang telah ditentukan.

\section{e. $\quad$ Staff e-commerce}

Shoppe, Tokopedia, Lazada, dan Bukalapak akhirnya memutuskan merekrut karyawan akibat peningkatan pesanan melalui online.

\section{f. Freelancer}

Semenjak seluruh masyarakat dihimbau untuk melakukan kegiatan di rumah, terjadi peningkatan freelancer dalam bidang jasa terutama bagian design. Kegiatan tersebut dapat menghasilkan uang tanpa mengganggu kegiatan yang lain.

\section{g. $\quad$ Programmer}

Perubahan dari sistem kerja manual menjadi digital membuat terjadinya peningkatan pekerjaan bidang programmer. Maka beberapa perusahaan membutuhkan sebuah sistem terintegrasi yang 


\section{Nadella, Dedi Rianto Rahadi}

dapat membuat alur kerja lebih mudah, seperti pengumpulan data, tanda tangan secara online serta validasi file lainnya dalam hitungan detik.

h. Akuntan Publik

Pandemi ini setiap perusahaan harus memastikan laporan keuangan serta konsekuensi pajak yang membuat pekerjaan akuntan mengalami peningkatan. Perusahaan menilai bahwa akuntan lebih netral dibanding audit.

i. $\quad$ Pekerja Konstruksi

Terjadinya peningkatan proyek pembangunan seperti rumah membuat perusahaan proyeksi melakukan prekrutan karyawan yang berasal dari teknik sipil hingga kuli bangunan.

j. $\quad$ Produsen Masker Kain

Pemerintah telah melakukan himbuan penggunaan masker untuk menghindari penyebaran virus korona. Himbauan tersebut menjadi peluang usaha masker kain sehingga terjadinya peningkatan permintaan.

Menurut katadata.co.id, perusahaan akan semakin ketat dalam memilih calon pekerja dimana setiap institusi menggunakan beberapa metode dalam mendapatkan pekerja yang memiliki kompetensi yang tinggi. Pada masa pandemi COVID 19 ini terjadi peningkatan pengangguran akibat PHK yang terpaksa dilakukan oleh perusahaan. Peningkatan tersebut dikemukakan oleh Mentri Ketenagakerjaan yang benama Ida Fauziah, dimana peningkatan tersebut mencapai 2,97 juta hingga 5,23 juta orang pada tahun ini. Saat di Istana Merdeka pada 18 Juni 2020, Ida Fauziah juga mengatakan akan berusaha menekan angka pengangguran agar tidak mencapai 2 digit. Melansir dari Business Insider, LinkedIn merilis lima soft skill yang paling dibutuhkan perusahaan pada tahun ini :

\section{Kreatifitas}

Kreatif dan pemecahan masalah merupakan dua hal yang dibutuhkan perusahaan saat ini karena dinilai tidak bersifat kaku maupun dinamis.

\section{Persuasi}

Persaingan yang ketat terhadap competitor, membuat perusahaan membutuhkan pekerja yang memliki kemampuan yang dapat meyakinkan ide yang dimilikinya.

\section{Kolaboratif}

Kemampuan menggambungkan ide pribadi dengan yang lain dinilai terdapat nilai tambah dalam bekerja di perusahaan. Hal tersebut dikarenakan dianggap berkompeten dalam bekerja sama dengan tim.

\section{4. $\quad$ Adaptif}

Semenjak pandemi ini terjadi perusahaan mengharapkan karyawan yang dapat beradaptasi dengan cepat.

\section{Kecerdasan emosional}

Perusahaan membutuhkan karyawan yang dapat mengelola emosinya dengan baik. Tekanan yang cukup tinggi terjadi dapat membuat seseorang menjadi stress dimana hal tersebur dapat 


\section{Nadella, Dedi Rianto Rahadi}

mengganggu perfoma perusahaan sehingga perusahaan mengharapkan karyawan dapat mengendalikan itu dengan sebaik mungkin.

Menurut uptown.id, kemampuan dari seorang karyawan sangat dibutuhkan oleh perusahaan untuk menciptakan keefisienan dalam sebuah pekerjaan. Pemberlakuan gaya kerja baru atau yang dapat kita sebut The New Normal akibat pandemi covid 19 yang terjadi membuat persaingan dalam dunia kerja menjadi semakin ketat. Terdapat 7 skills yang dibutuhkan saat pandemi ini adalah :

\section{Kemampuan Beradaptasi}

Perusahaan sudah menjadi keharusan dalam menaati peraturan pemerintah. Saat ini pandemi korona yang mengguncang beberapa negara membuat setiap pekerjaan ataupun tanggung jawab harus dikerjakan di rumah. Sebagai contoh nyata bahwa setiap pekerja dianjurkan mulai terbiasa menggunakan layanan online seperti video call sebagai perubahan diskusi tatap muka. Perubahan tersebut membuat setiap perusahaan membutuhkan karyawan yang mampu beradaptasi pada kondisi tertentu.

\section{Berpikir Kritis}

Semasa pandemi korona ini menimbulkan banyak berita yang terbilang tidak sesuai kenyataan atau biasa kita dapat sebut yaitu berita hoax. Agar tidak termakan berita tersebut, perusahaan sangat membutuhkan karyawan yang dapat beripikir secara kritis. Kemampuan itu sangat dibutuhkan perusahaan untuk meningkatkan kembali perekonomian yang sempat mengalami penurunan akibat pandemi covid 19 ini.

\section{Kreatifitas dan Kemampuan Berinovasi}

Perusahaan di tengah pandemi ini membutuhkan karyawan yang dapat menciptakan ide- ide unik serta kreatif agar dapat menghasilkan keuntungan dalam jumlah banyak. Dimana hal tersebut dikarenakan banyak perusahaan yang berusaha berinovasi di saat sulit seperti ini, mulai dari restoran yang mulai mengambil pesanan secara online, bisnis fashion yang membuat masker dari sisa kain, serta pengusaha kopi yang berinovasi menyediakan minuman dalam bentuk botol literan.

\section{Analisis Data}

Dalam membangun kembali perusahaan mengenai pengambilan keputusan, perusahaan membutuhkan seorang analis data. Bagian tersebut sangat berguna selepas pandemi korona berakhir nantinya bagi sebuah perusahaan. Seperti yang dikatakan Fast Company, perusahaan mesti menganalisa konsumen, permintaan pasar, dan sebagainya dari data- data yang telah dikumpulkan.

\section{Keterampilan Teknologi}

Keterampilan teknologi seperti paham dalam membentuk kecerdasan buatan atau yang dapat kita sebut Artificial Intellegence, pembuatan Big Data dan sebagainya sangat perlu dipersiapkan setiap individu dalam kondisi pandemi korona atapun setelahnya untuk menjadi alternatif yang merupakan bekal individu ke depannya.

\section{Digital/ Social Marketing}

Kondisi pandemi ini membuat bidang pekerjaan Digital/ Social Marketing banyak diberikan oleh perusahaan. Keahlian yang dapat dipelajari seperti SEO atau yang dapat disebut Search 


\section{Nadella, Dedi Rianto Rahadi}

Engine Optimization, kemudian SEM atau Search Engine Marketing, serta email marketing oleh sejumlah individu. Keahlian-keahlian tersebut seperti yang dikatakan Fast Company dapat membantu perusahaan dalam melakukan personal branding atau dalam kata lain membangun kembali brand perusahaan tertentu di masa yang akan dating.

\section{Kecerdasan Emosional}

Perusahaan dan para karyawannya berusaha menciptakan suasana yang posiitf dengan kerjasama yang lebih baik dengan sesama karyawan serta menekan keresahan klien. Hal tersebut membuktikan bahwa setiap perusahaan membutuhkan karyawan yang memliki kemampuan kecerdasan emosional. Keadaan pandemi ini membuat emosional setiap individu dipertaruhkan dikarenakan banyak hal yang belum berjalan stabl bahkan selepas pandemi ini nantinya. Kecerdasan emosional setidaknya memberikan $80 \%$ mengenai faktor kesuksesan dari setiap individu maupun organisasi sedangkan $20 \%$ berasal dari IQ, hal tersebut dikatakan oleh Daniel Goleman di dalam penelitiannya di tahun 2000. Kecerdasan emosional atau yang dapat kita sebut EQ juga merupakan kemampuan untuk menyadari, mengontrol emosi, serta mengekspresikan emosi diri sendiri maupun memahami emosi orang lain.

Menurut resource.urbanhire.com, pengembangan atau yang dapat kita sebut pelatihan terhadap para karyawan menjadi agenda yang tertunda sehingga perusahaan perlu melakukan tindakan untuk mengembalikan atau memulai kembali agenda tersebut. Hal tersebut menjadi tantangan baru untuk para HR untuk tetap melakukan pengembangan pada saat pemerintah memberlakukan Physical Distancing ataupun WFH. Pengembangan tersebut dapat dilakukan dengan cara online. Cara-cara tersebut ialah :

\section{Atasan Ikut Berpartisipasi}

Keterlibatan langsung dari CEO ataupun atasan dari sebuah perusahaan dalam sebuah pelatihan dapat membantu meningkatkan keselarasan seluruh karyawan dan peningkatan keterlibatan. Tindakan seperti itu dapat membantu meningkatkan rasa antusias para karyawan dikarenakan mereka merasa langsung mendapatkan ilmu dari atasan sebuah perusahaan dalam kegiatan pengembangan. Maka dari itu, tindakan tersebut dapat menjadi langkah awal perusahaan dalam melakukan pengembangan.

\section{Tambahkan Hal-hal Interaktif}

Kegiatan- kegiatan yang dinilai memiliki unsur interaktif dapat dilakukan atasan perusahaan untuk menarik perhatian para karyawan dalam kegiatan pengembangan. Pelatihan dapat dilakukan dengan pembagian waktu presentasi menjadi maksimal 30 menit dan sisa waktu dapat digunakan untuk berinteraksi langsung dengan memberikan praktik pelatihan dan timbal balik mereka. Keterbatasan interaksi dan jarak menjadi tantangan tersendiri dalam melaksanakan pelatihan secara online.

\section{Mempertahankan Sentuhan Manusia}

Dalam melaksanakan program pengembangan, untuk mencapai hasil yang baik dan efektif, perusahaan dapat melakukan sesi berdiskusi ataupun saling bertukar hal lucu yang dapat membuat karyawan tetap berinteraksi dengan sesama partner. Hal tersebut menjadi tantangan selanjutnya, dimana perusahaan mempertahankan sentuhan manusia walaupun melakukan kegiatan pengembangan melalui daring. 


\section{Nadella, Dedi Rianto Rahadi}

\section{Pembahasan}

Dari berita-berita yang telah diambil dari beberapa website terpecaya serta wawancara yang telah dilakukan terlihat beberapa kompetensi yang dapat dikembangkan serta dipelajari oleh karyawan dan calon karyawan untuk bertahan ataupun memulai masuk ke dunia kerja di masa pandemi ini. Kompetensi-kompetensi yang diharapkan perusahaan di masa pandemi ini tidak jauh dari Information Technology ,Financial, dan Customer Service.

Berdasarkan hasil wawancara dari kedua narasumber, Customer Service menjadi salah satu pekerjaan yang sangat dicari di masa pandemi ini. Hal tersebut dikarenakan untuk membantu pelaksanaan kegiatan ekonomi yang dilakukan serba digital atau online. Dengan hal itu, pemilik usaha online, dimana di masa pandemi ini semua dialihkan serba online sehingga peningkatan e-commerce terjadi membuat mereka membutuhkan para calon karyawan yang dapat berkomunikasi dengan baik serta menguasai skill-skill yang berkaitan dengan Customer Service.

Kompetensi Information Technology sangat dibutuhkan dikarenakan masa pandemi ini menuntut setiap pekerjaan untuk bekerja di rumah, dimana semua akan dilakukan melalui digital. Dalam mengintegrasi seluruh data karyawan serta operasional perusahaan membutuhkan bagian IT untuk membuat pekerjaan tersebut berjalan dengan lancar. Kompetensi Information Technology juga dibutuhkan karena mempersiapkan perkembangan zaman dimana semua akan serba digital.

Kompetensi Financial juga sangat dibutuhkan oleh perusahaan ataupun badan usaha. Hal tersebut dikarenakan perusahaan membutuhkan seseorang yang berkompeten menghitung serta menganalisa pajak di masa pandemi ini. Data pemasukan serta pengeluaran pun tetap dibutuhkan setiap perusahaan untuk memastikan operasional tetap berjalan dengan lancar.

Peningkatan usaha online terjadi di masa pandemi ini dikarenakan hal tersebut tetap bisa dilakukan bahkan menjadi mata pencaharian utama di saat work from home dilakukan.Ecommerce sangat membutuhkan customer service untuk menjalankan suatu usaha, hal tersebut membuat kompetensi customer service sangat dibutuhkan di masa pandemi covid 19 ini.

Dalam mengembangkan kompetensi-kompetensi yang dibutuhkan perusahaan harus dilengkapi softskills tertentu agar kompetensi yang dimiliki dapat diasah dengan baik. Perusahaan juga menentukan karyawan baru yang masuk dari kepribadian ataupun perilaku seseorang. Softskills yang bisa dikembangkan saat kondisi pandemi covid 19 ini yaitu kemampuan beradaptasi, kreatif serta kecerdasan emosional. Kemampaun beradaptasi dibutuhkan karena terjadinya perubahan besar saat pandemi ini, dimana kita harus tetap berkompeten dalam sebuah pekerjaan yang awalnya secara offlline menjadi online. Hal itu membuat perusahaan tetap mempercayai kita tetap bisa bekerja di kondisi apapun. Emosi seseorang sangat berpengaruh terhadap perfoma perusahaan, pada masa pandemi ini dimana segala sesuatu serba sulit, maka kita sebagai pekerja harus pandai dalam mengatur emosi agar tetap memastikan pekerjaan dilakukan dengan baik dan lancar. Para karyawan ataupun seorang entrepreuner muda yang baru mengawali karir membutuhkan kreatifitas untuk menciptakan keunikan serta membuat usaha tersebut dapat berjalan dalam jangka panjang.

Dalam mengembangkan kompetensi-kompetensi tertentu yang mengandung hardskills membutuhkan training yang dilakukan oleh HR kepada para karyawan baru. Pandemi covid 19 


\section{Nadella, Dedi Rianto Rahadi}

ini tidak memungkinkan training dilakukan di perusahaan dengan jumlah pekerja yang sangat banyak, di lain sisi perusahaan ataupun badan usaha harus tetap melaksanakan training untuk memastikan operasional dari usaha tersebut dapat tetap berjalan dengan lancar, maka dari itu semua HR beralih ke training secara online. Melakukan pelatihan ataupun pengembangan kompetensi bukan perkara yang mudah serta terdapat beberapa hambatan seperti jaringan, kepastian tingkat mengerti para karyawan serta mempertahankan pembangunan komunikasi antar karyawan dan dengan atasan. Dalam memastikan training dapat berjalan dengan lancar, seorang HR harus melakukan beberapa cara agar setiap karyawan dapat menangkap semua kegiatan training, cara-cara tersebut ialah pemimpin perusahaan bisa mengikuti training online untuk pengenalan lebih dekat dengan para karyawan baru serta membuka diskusi untuk membuat hubungan karyawan serta atasan bisa semakin erat.

\section{Kesimpulan}

Pandemi covid 19 mulai mengguncang negara Indonesia pada awal Maret 2020, dimana semua pekerjaan harus dihentikan sementara dengan bekerja dari rumah. Sebagian perusahaan juga menerapkan PHK yang menyebabkan angka pengangguran semakin meningkat. Selama work from home terjadi, setiap pekerja dituntut untuk menyelesaikan tanggung jawabnya melalui perangkat yang mendukung.

Dalam menghadapi kondisi ini membuat setiap orang harus berpikir bagaimana bertahan di sebuah pekerjaan maupun mencari bekerja untuk bertahan hidup. Masa pandemi ini membuat banyak perusahaan meminimalisir pencarian pekerjaan. Akan tetapi ada beberapa pekerjaan tetap dibuka oleh sejumlah badan usaha. Bagi seseorang yang memiliki kompetensi Information Technology, Financial, serta Customer Service memiliki banyak peluang di masa pandemi ini. Hal tersebut dikarenakan pandemi ini setiap pekerjaan dilakukan dengan serba digital dan terjadinya peningkatan di bidang usaha online. Dalam menjalankan perusahaan, pencatatan pendapatan, pengeluaran, serta pajak tetap menjadi bagian tanggung jawab perusahaan di kondisi apapun termasuk saat pandemi ini, hal tersebut membuat kompetensi financial masih sangat dibutuhkan saat ini.

Para pemilik usaha seperti Serendiptydesign dan Herskinnn juga sangat membutuhkan para calon karyawan yang menguasai bidang Customer Service. Peningkatan e-commerce terjadi karena kegiatan ekonomi saat ini dipaksa untuk dilakukan di rumah untuk menahan seluruh penyebaran virus ini. Peningkatan tersebut membuat kedua pelaku usaha tersebut membuka lowongan pekerjaan yang dapat membantu jalannya usaha dengan mempertimbangkan skill pekerjaan tersebut seperti mampu berkomunikasi dengan baik.

Softskills yang menjadi pertimbangan perusahaan seperti kecerdasan emosional, adaptif, dan kreatif juga sangat dibutuhkan oleh setiap perusahaan untuk menjadi perfoma perusahaan. Perusahaan mengharapkan karyawan ataupun calon karyawan memliki kompetensi tersebut. Dalam mengembangkan kompetensi tersebut dapat dilakukan dengan cara training online dengan melakukan interaksi untuk mempererat hubungan antara pelamar maupun pemberi kerja.

\section{Daftar Pustaka}

Endah Pratiwi, Nur. 2018. PENGARUH DIMENSI KOMPETENSI TERHADAP KINERJA PEGAWAI PADA DINAS TENAGA KERJA KOTA CIMAHI. Thesis Universitas Pasudan. 


\section{Nadella, Dedi Rianto Rahadi}

KemnkeuRI.2019. Memahami Metode Penelitian Kualitatif. https://www.djkn.kemenkeu.go.id/artikel/baca/12773/Memahami-Metode-

PenelitianKualitatif.html (diakses pada tanggal 14 Oktober 2020)

Mardin Amin,Namira.2015. PENGARUH KOMPETENSI TERHADAP KINERJA PEGAWAI DI SEKRETARIAT DAERAH KABUPATEN SIDENRENG RAPPANG.Thesis Universitas Hasanuddin

Markey.2019. Pengembangan SDM Tujuan, Manfaat \& Ruang Lingkupnya. https://markey.id/blog/bisnis/pengembangan-sdm (diakses pada tanggal 4 Oktober 2020)

Maxmanroe. Pengertian Kompetensi: Definisi, Jenis-Jenis, dan Manfaat Kompetensi. https://www.maxmanroe.com/vid/manajemen/pengertian-kompetensi.html (diakses pada tanggal 4 Oktober 2020 )

Om.makplus.2015.Pengertian Konsep Pengembangan. http://www.definisipengertian.com/2015/05/pengertian-konsep-pengembangan.html ( diakses tanggal 4 Oktober 2020 )

Satgas Covid19.2020. Peraturan Pemerintah Republik Indonesia Nomor 21 Tahub 2020 Tentang PSBB. https://covid19.go.id/p/regulasi/pp-no-21-tahun-2020-tentang-psbbdalam-rangka-penanganan-covid-19, (diakses pada tanggal 6 Januari 2021)

Sorta,Tobing.2020. Lima Soft Skill yang Wajib Dimiliki Pencari Kerja di Masa Pandemi. https://katadata.co.id/sortatobing/berita/5f1ef0c309a3b/lima-soft-skill-yang-wajibdimiliki-pencari-kerja-di-masa-pandemi (diakses pada tanggal 29 September 2020)

Detik.com, T. (2020). Kapan Sebenarnya Corona Pertama Kalo Masuk RI. Retrieved from https://news.detik.com/berita/d-4991485/kapan-sebenarnya-corona-pertama-kalimasuk-r

Tim,CNN Indonesia.2020. 10 Pekerjaan yang Laku di Masa Pandemi Corona. https://www.cnnindonesia.com/gaya-hidup/20200702112635-284-519969/10pekerjaan-yang-laku-di-masa-pandemi-corona ( diakses pada tanggal 29 September 2020 )

Uptown.2020. INI DIA 7 SKILL YANG HARUS DIMILIKI SETIAP KARYAWAN SETELAH PANDEMI. https://uptown.id/id/2020/06/18/ini-dia-7-skill-yang-harusdimiliki-setiap-karyawan-setelah-pandemi/ ( diakses pada tanggal 29 September 2020)

Urbanhire.2020 Pengembangan Karyawan Di Tengah Pandemi. https://resources.urbanhire.com/pengembangan-karyawan-di-tengah-pandemi/ (diakses pada tanggal 29 September 2020)

WHO.2020.Q\&A on coronaviruses (COVID19).https://www.who.int/emergencies/diseases/novel-coronavirus-2019/question-andanswers-hub/q-a-detail/q-a-coronaviruses\#: :text=symptoms ( diakses pada tanggal 4 Oktober 2020 )

Yostan AL. 2019. Konsep Pengembangan Sumber Daya Manusia Berbasis Kompetensi, Bakat dan Ketahanan dalam Organisasi. Sumber Daya Manusia. 7(1): 2-3. 